\title{
Engaging with Bourdieu: A review of the utilisation of Bourdieu within children and young people's geographies
}

Christina R. Ergler, University of Otago, Dunedin, New Zealand;

christina.ergler@otago.ac.nz

Bronwyn E. Wood, Victoria University of Wellington, Wellington, New Zealand;

Bronwyn.wood@vuw.ac.nz

Ergler, C., \& Wood, B. E. (2018). Engaging with Bourdieu: A review of the utilization of Bourdieu within Children and Young people's geographies. In T. Skelton \& S. Aitken (Eds.), Establishing Geographies of Children and Young People (Vol. 1, pp. 147-169). Singapore: Springer Nature Singapore.

\begin{abstract}
While the work of Pierre Bourdieu has had a significant impact on the fields of anthropology, educational research and cultural studies, his ideas have much less commonly been used by geographers. In this chapter, the authors review Bourdieu's central concepts and ideas and then examine how Bourdieu has been utilised within research in children and young people's geographies to enhance understandings of children, space and social justice. This analysis reveals that singular concepts of Bourdieu's (social and cultural capital) have been applied with some frequency but that his integrated conceptual triad or complete theory of practice has much less commonly been used. The chapter concludes with some examples of how more in-depth approaches through Bourdieu could support richer understandings of children and young people's geographies.
\end{abstract}

Keywords: Bourdieu, social capital, cultural capital, habitus, children's geographies, space 


\section{Introduction}

Pierre Bourdieu is regarded as one of the foremost social philosophers of the twentieth century, contributing insights into fields as diverse as economics, politics, art and theology (Grenfell, 2008a). Yet, while the work of Pierre Bourdieu has had a significant impact on the fields of anthropology, educational research and cultural studies, his ideas have much less commonly been used by geographers (Bridge, 2004, Popay et al., 2003, Stetten, 2009). Notable exceptions include Harvey (1987, Harvey, 1989), Gregory (1994) and Pile and Thrift (1995) who were some of the earlier geographers to recognise the potential of Bourdieu's contribution to improved understandings of society, inequalities and space. Yet, although Bourdieu provides a complex and fine-grained conceptual framework for analysing the social and physical world, he is, according to Painter, a "social theorist whom geographers cite frequently, but rarely engage with in any depth" (Painter, 2000, 246). The purpose of this chapter is to examine how Bourdieu's theories and concepts have been applied within the subdiscipline of children's geographies, and to consider the impact and contribution of Bourdieu's ideas on understandings of children and space.

This chapter is subdivided in three sections. Section I briefly introduces Bourdieu's triad of capital, habitus and field - aspects of the conceptual triad in his theory of practice (Bourdieu, 1977; 1990). Section II provides a review of a selection of research that has engaged with these concepts in the sub-discipline of children's geographies and considers the contribution that these studies have made to deeper understandings of children, space and social justice. The final section, Section III, illustrates two further examples of Bourdieusian applications in two different fields of research drawing on the authors' work, concluding with a series of implications and notes for future research.

\section{Section I: Bourdieu's intertwined key concepts: field, capital, habitus}

Bourdieu's work is characterised by two features: first, a particular understanding of the link between theory and practice and second, a set of conceptual tools which can be applied to diverse fields of study in the course of analysis (Grenfell, 2008a). The attention he drew to the link between theory and practice centred in particular upon the question, "what motivates human behaviour?" (Hillier and Rooksby, 2002, 4) Rather than turning to psychology for an explanation, he proposes that the actions of individuals are a reflection of the interaction of 
different social fields that combine to transform or reproduce patterns produced by the interplay of structure and agency. Bourdieu describes his approach as a "constructivist structuralism or structuralist constructivism” (Bourdieu, 1990, 112). Thus, the practices of individuals and groups can be seen to be a result of the dialectic interplay of objective and subjective structures. His approach is sometimes therefore referred to as having a 'middling tendency' (Threadgold, 2010) and trying to unpack people's 'points of view' in relation to their structural life circumstances (Bourdieu et al., 1999). This implies that actors can influence and transform their social realities within the structures that shape their everyday life and that they are also able to hinder, contribute to or foster social change (Bourdieu, 1984).

The second feature of his work is the development of a set of analytical conceptual tools: habitus, capital and field (Bourdieu, 1990, 1977). Bourdieu referred to the concepts he developed as adaptable 'tool kits' to help him solve problems:

The peculiar difficulty of sociology then, is to produce a precise science of an imprecise, fuzzy, woolly reality. For this, it is better that its concepts are supple and adaptable, rather than defined and calibrated and used rigidly. (Bourdieu and Wacquant, 1992, 23 ) ${ }^{1}$

His argument is that there is a need for 'supple' and 'adaptable' concepts which are to be applied and reapplied in differing theoretical and situational frameworks and to be tested again and again. Thus, in his view, concepts are always to be wedded to theory and research as a form of "fusion of theoretical construction and practical research operations" that causes them to "interpenetrate each other entirely" (Bourdieu and Wacquant, 1992, 34-35). While these concepts are closely intertwined, they will be artificially taken apart in the following paragraphs to provide a brief introduction to each one individually as a foundation for the critical review of studies applying Bourdieu's work in section II.

Bourdieu contests that to understand social life, a focus upon the social space, or field (the term he uses) in which interactions, transactions and events occur is necessary. Such a field has its own 'cosmos' determined by particular (arbitrarily defined) regulations and patterns of operation; its own sets of belief in 'appropriate' actions, which have been developed over time (Thomson, 2008). For example, Bourdieu refers to artistic, religious, or

\footnotetext{
${ }^{1}$ We cite Bourdieu's book with Loic Wacquant (1992) on many occasions in this section as this dialogical book between Bourdieu and Wacquant provides a very useful analysis and summary of Bourdieu's 'reflexive sociology'. We see this book as a good resource for starting to engage with Bourdieu's tool kit as Bourdieu outlines his thinking in an accessible way.
} 
economic fields, each one containing its own logic, networks and practices that are specific to that field (Bourdieu and Wacquant, 1992). Hence, each field has its own logic of practice, its own "conflicts and competitions" (Bourdieu and Wacquant, 1992, 17). Bourdieu often referred to this concept of field with an analogy of a game in which the inhabited positions of agents in this social space reflect their knowledge of how to play 'the rules' of the game, or how to use their capital endowments to pursue their desires. Agents with 'more' power hold the knowledge that is "valued, sanctioned and rewarded" (Crossley, 2008, 96). In this way, a field can be seen as "a site of struggle over a particular form of capital" (Harker, 1990, 97). Hence, Bourdieu's fields are not static. They are the result of many contestations of positiontaking and distinction, but the chance of success rises the more familiar one is with the rules structuring a field in relation to one's capital.

Broadly speaking, capital is effectively the resources which actors take to the field (Hillier and Rooksby, 2002). Bourdieu proposes a variety of "capitals" that individuals can possess: these include social, cultural, economic and symbolic capitals (Bourdieu, 1986) which are resources that agents accrue during their life course (Holt, 2008, 234). For example, cultural capital refers to the knowledge, skills and information people acquire through formal or informal education, while economic capital refers to the income and assets people own. Bourdieu proposes that cultural capital can exist as an embodied state (such as jargon, music), an objectified form (such as books, scientific instruments) and in an institutionalised form, most often represented by educational credentials (Bourdieu, 1986). Social capital is another asset that holds relative advantage in society. Bourdieu refers to social capital as the sum of resources (actual or virtual) that accrue to an individual or group as a result of social connections and relationships (Bourdieu and Wacquant, 1992). According to Bourdieu, one form of capital is necessarily understood within the context of other related capital: "it is in fact impossible to account for the structure and functioning of the social world unless one reintroduces capital in all its forms and not solely in one form" (Bourdieu, 1986, 15).

Bourdieu points out that these forms of capital are not valued equally in society. Instead, a system of exchanges differentiates between these and awards some forms of capital with greater value - or symbolic capital - than others (Bourdieu, 1986). Therefore, the capitals of some groups are arbitrarily deemed more valuable than others, and conferred with social advantage as they come to be understood to hold "qualitative differences in forms and consciousness within different social groups" (Moore, 2008, 102). Moreover, Bourdieu (1977) suggests that capitals need to be understood to exist within the logic, networks and practices 
of a field - or the social space within which individuals operate (Bourdieu and Wacquant, 1992) and the habitus (or dispositions people embody as a result of social conditioning (Bourdieu, 1977). In other words, capital endowment structures not only the power and agents' social position within a field, but also the interests and attitudes an agent possesses (habitus), which in turn affects how actors react when confronted with different social situations.

Habitus is the concept Bourdieu developed to describe the dispositions that embody both individuals and groups as a result of their social conditioning within that context of a group. It is the thinking tool with which Bourdieu attempts to provide the "mediating link between objective social structures and individual actors" (Painter, 2000, 242). Habitus can be understood as partially, unconsciously developed embodied dispositions (e.g. norms, patterns of behaviour, taste) through which the world is perceived, experienced, evaluated, felt, shaped and acted upon (Bourdieu and Wacquant, 1992). These dispositions are inscribed in bodies and "schemata of perception, appreciation, and action" and move beyond the conscious sphere of everyday life (Bourdieu and Wacquant, 1992, 16) as they ease the mastering of the complexities of a field or the world in general. Through these embodied schemata, agents draw unconsciously on the 'right rationale' for acting in the appropriate way in the majority of situations. Thus, agents' practices or pre-reflexive actions become a so-called 'second nature' as they respond intuitively with a sense of the 'social game' that corresponds with their social class or position in society. This means the habitus can be understood as a feel for the regularities appropriate to the field in question formed by and forming dispositions that mark social distance and social position.

Habitus therefore serves as the classificatory basis for individual and collective practice, while (re)producing the structures (social and physical aspects) from which it is derived. Or, in Creswell's $(2002,381)$ words, "the habitus represents the internalisation of the social order, which in turn reproduces the social order." This means that the habitus of an individual is bounded and constructed within the limits of personal experiences (past), socialisation processes and the historical conditions of its production (history). These ideas describe how social reproduction, or the tendency for social class patterns to reproduce in the next generation, can occur - which has led many (e.g. Jenkins, 1992, Butler, 1999) to accuse Bourdieu of fatalistic determinism. However Bourdieu is quick to point out that: 
Being the product of history, [habitus] is an open system of dispositions that is constantly subjected to experiences, and therefore constantly affected by them in a way that either reinforces or modifies its structures. It is durable but not eternal! (Bourdieu and Wacquant, 1992, p. 133)

Despite Bourdieu's assertions of looking at structural and agentic dimensions simultaneously, he has frequently been viewed as a structuralist and dismissed by poststructuralists and others; possibly because he never developed a theory of agency as clearly as he developed a theory of social reproduction, even though through his concept of habitus, it is possible to see such potential.

\section{Bourdieu and space}

Although the social space - as outlined in the previous paragraph - is always the starting point for Bourdieu's thinking, the physical and social space nonetheless build a relational entity in his understanding of the creation of inequalities within a field. Although both spaces build an entity it has nonetheless to be noted that in Bourdieu's eyes, physical space only mirrors (at least partially) the social space (Bourdieu, 2000, 134). He simply translates the positions occupied in social space into the physical space both literally and symbolically. Thus, social patterns engrave themselves into the physical space as exemplified already in his earliest writings about the everyday practices taking place in an Algerian Kabyle house. The physical layout of the house mirrors the spatialised practices such as cooking, farming, eating, sleeping of a Berber family and reflects on a more abstract level their cosmological beliefs about gender, life and death (Bourdieu, 1990). Thus, the physical space for Bourdieu is only a symbol for the embodied structures of society cementing potentially the distinctive role of the physical space in producing social inequalities (Bourdieu, 1999, p. 134). This idea is particularly well developed in his edited collection The Weight of the World (Bourdieu et al., 1999). Here he describes a place, such as Jonquil Street, with a great deal of sensitivity to the local residents' lives in the context of industrial decline and the limited life chances. Nonetheless, although Bourdieu uses a "spatialised vocabulary" (Painter, 2000, p. 255), he does not richly theorise social or material space in his writings and nor were geographic ideas strongly present in his primary period of writing (before the 1990s).

Although geographers such as Cresswell (2002) praise Bourdieu for his attention to "social space" and inequalities throughout his work, they critique his limited contribution to a 
deeper understanding of "space" (Bridge, 2001; Gregory, 1994; Painter, 2000). Some even warn of a spatial trap embedded in his spatial understanding (Lossau and Roland, 2004, Holt, 2008). In particular, the children's geographer Louise Holt (2008) criticises Bourdieu for treating space as a static, pre-existing "given", rather than engaging with and encompassing the critical and complex conceptualisation of space and spatiality forwarded by geographers such as Massey (2005). Feminist scholars have also critiqued Bourdieu for underestimating the ambiguities which exist in the way that men and women occupy gender positions and for how these gendered positions are being remade in new ways (Kenway and McLeod, 2004).

While Bourdieu only published a handful of direct references outlining his thoughts on the interaction between social and physical space (Painter, 2000), Cresswell (2002) suggests that this absence can be viewed as an opportunity for geographers to offer a less instrumental interpretation of Bourdieu's work. It provides freedom for children's geographers to operationalize and extend Bourdieu's thinking in fresh and unexpected ways. This approach was endorsed by Bourdieu himself, who encourages his readers to extend his work theoretically, practically and methodologically by utilising it in new research questions (Bourdieu and Wacquant, 1992). This quest has been taken up by a handful of children's geographers, introduced in more detail in the next few sections. Nonetheless, the majority have only applied his concepts lightly and often in isolation for unpacking the production, reproduction and experience of inequality and thus neglect the opportunities a full engagement with his triad might offer a fuller understanding of children's (non)participation in particular spaces of society in relation to their 'points of view' and wider life circumstances.

\section{Section II: Engaging with Bourdieu in children's geographies}

In this section, we examine the scholarship of some of the researchers who are working at the intersections of children/young people, space and Bourdieu. We focus on papers which have applied Bourdieu's theories and concepts to contexts which relate to children and young people and space in the broadest sense. Many such papers appear within journals such as Children's Geographies Children, Youth and Environments, and Urban Studies and in key publications (e.g., Aitken, 2001, Holt, 2011, Hörschelmann and Van Blerk, 2012). The papers discussed here provide a taste of some of the ways Bourdieu has been applied. Given the space constraint selectivity had to be exercised, but there were more works that could have been included. When we examined these articles, we were interested in how researchers had 
applied Bourdieu's concepts and to what end. It was apparent that many studies only cite Bourdieu in passing, or engage with his concepts and theories lightly. The examples included in this section tended to have a more robust application of Bourdieu, although most of them still choose to focus on one or two aspects of his theory rather than the interlinked conceptual triad presented earlier. Thus the following sections trace and reflect on the operationalization of his two most popular concepts, social and cultural capital, and his notion of habitus in children's geographies. This section concludes with an analysis of the nature of engagement with Bourdieu within geographies of children and young people.

Social capital: The most wide-spread application of Bourdieu by researchers working within children's geographies has been the use of his concept of social capital. Holland (2008) explains that social capital is a controversial but surprisingly popular concept. One reason for the prevalence of this concept is that social capital has been more widely theorised than many of Bourdieu's other 'capitals'. Beyond Bourdieu, Robert Putnam (1993,1995, 2000), James Coleman (1988) and Fukuyama (2001) have also contributed to defining and exploring social capital. While the focus of this chapter is upon Bourdieu's conceptualisation of social capital, it is important to acknowledge a significant body of work by researchers exploring children, families and geography who have applied Putnam's conception of social capital (for examples, see Reynolds, 2013, Goodwin and Armstrong-Esther, 2004, Turner and An Nguyen, 2005).

A further reason for the popularity of social capital was the integration of notions of social capital within a number of social policies in the 1990s associated with the 'Third Way'. These were popular in the United States (under Bill Clinton) and the United Kingdom where it was closely linked to the rise of Tony Blair's 'New Labour' government (Giddens, 1998). Such policies placed a strong emphasis on promoting social inclusion and community responsibility for social issues, marked by a parallel shift of governmental responsibility away from provisions previously made through state welfare. During this time, social capital became a common feature of policy discussions and research, especially as it provided noneconomic solutions to social problems (Portes, 1998). Accordingly, it has become a key feature of research in subsequent years, including within research in geographies of children and young people.

One of the earliest utilisations of Bourdieu's social capital concept for children's research was Virginia Morrow's seminal work in community development, health and 
wellbeing, and citizenship participation (1999, 2000, 2001). Morrow's work has been drawn on by researchers of children and young people's geographies as it illustrates how children themselves hold and develop social capital, thus critiquing the passive way that theorists such as Putnam viewed children's social capital (Morrow, 2000). Her work also importantly contributed to widening the definitions of children's well-being by focusing on broader aspects such as community participation, informal social networks and belonging (Morrow, 2001 and 1999). While Morrow uses both Putnam and Bourdieu in her work, she argues that Bourdieu's concept is stronger as it can encompass wider definitions of social and health factors than Putnam's definitions can, and also provides opportunities to connect with other capitals, and wider economic and political structures (unlike Putnam's conceptualisation) (Morrow, 2001).

Building upon Morrow's conceptualisation, researchers investigating children, young people and space have considered the ways in which children themselves generate and build social capital. For example, Susie Weller's (2006) research examining the citizenship practices of young people on the Isle of Wight shows how social capital provides a framework for not only analysing the 'disadvantages' of young people, but also the resourceful ways in which many use their social capital to overcome these disadvantages. She proposes that many young people were 'active social capitalists' (p. 572), using their social networks and connections to revitalise their facilities and improve their neighbourhoods. This notion is in contrast to prior research where children were viewed as inheritors of social capital, but not contributors. Similarly, Weller and Bruegel's (2009) research concluded that children are "active agents in the development and maintenance of social capital at the level of the family and neighbourhood" (p. 641) through 'hanging out', helping neighbours and building social networks, thus contributing toward neighbourhood social capital.

Other researchers with a focus on cohesion and integration have also found social capital a valuable theoretical concept to explain the development (or failure to develop) community and social relationships. For example, Holton (2014) shows how the social capital held by tertiary students provides them with a way to navigate and 'fit in' to university halls of residence. Drawing on Bourdieu (1986), his research shows how halls of residence can perpetuate disadvantages in social capital, yet he highlights how non-traditional students can also transform or adapt contingent behaviours to maximise durable relationships with others. Social capital as also found to be an important (financial) asset for child domestic workers in 
Bangladesh, who were able to gain employment through networks they had made with former employees (Jensen, 2015). In a similar vein, a number of authors have also found social capital a useful theory to examine children's experiences of migration (Ní Laoire, 2011, Wells, 2011, Devine, 2009). For example, Ni Laoire (2011) describes the gendered nature of children's social interaction patterns of returned Irish families to Ireland, and Wells (2011) examines the social networks refugee children use to access resources and friendships in London. Devine (2009) examines the social (and cultural capital) that immigrant children in Ireland use and generate as they attempt to 'integrate' into Irish schools. These include making friends, learning the Irish language and sport, minimising aspects of cultural difference relating to accent, diet and dress in order to position themselves in a manner that enabled them to integrate into existing social networks or create new ones. These studies all highlight the complexity of social relations and the explanatory power of social capital to help untangle how it is utilised and generated by children.

Fewer researchers have applied social capital to discuss the reproduction of social privilege. Raffo and Reeves (2000) provide an example of such an approach to social capital in which they argue that young people's transitions from school to work and adulthood are conditioned by an interplay of material and symbolic resources available through social networks. They propose that young people have 'individualised systems of social capital' which are in turn spatially, culturally, temporally and economically embedded within their social relations. Another example is Holt's (2010, Holt et al., 2013) work on 'embodied social capital' which primarily focuses on the experiences of (dis)abled children with mind-body or socio-emotional differences. Her research illustrates how the social groups these children (re)produced were formed at intersecting practices of inclusion and exclusion, which were based around notions of similarity and difference (Holt, 2010, 2008). These aspects of identity carried a form of 'symbolic capital' in terms of highly valued commodities, showing how bodies are components of broader socio-spatial relationships which are valued differently in different contexts and by different groups (Holt, 2008: 242). In this way, Holt's work provides an excellent example of the potential value of social capital for geographical analyses of inequality and privilege.

In sum, these applications of social capital in research in children's geographies reveal a number of dimensions to their social relations. In this suite of discussed studies, social capital provides a lens to examine children's interactions, friendship and engagements. Social capital is therefore a useful tool or heuristic device for exploring social processes and practices 
around children's experiences of their environments, and in doing so, has highlighted young people's social resources (or lack of them) to shape and actively participate in their surroundings (Morrow 2001, 58). Applying Bourdieu's concept of social capital 'enables potential but largely invisible power relations to be recognised' (Weller, 2006, 571) and hence can be used to understand the life constraints of children and young people better. This analytical approach is enhanced when considering Bourdieu's other capitals (economic, cultural symbolic) and his concept of a 'field' of activity (Holt, 2008), a point returned to later in the chapter.

Cultural capital: Cultural capital has particular currency in the field of education; those who hold 'recognised' cultural capital are deemed competent and rewarded by long-term benefit for their educational pursuits (Devine, 2009). In turn, the prevailing way in which cultural capital has been applied within geographies of children has been in the context of education (for examples, see Asplund and Prieto, 2013, de Hoop, 2017, Hollingworth et al., 2011, Holloway and Pimlott-Wilson, 2011, Sparks, 2016), but also migration - which is frequently linked to education as well (Waters, 2006, 2014, 2017, Devine, 2009, Weenink, 2008). Cultural capital is a key influence on young people's identities, aspirations and subjectivities, as de Hoop (2017) demonstrates through her Bourdieu-informed study of south Indian young people's environmental subjectivities in the context of schooling, home life and understandings of modernity. Access to cultural capital, or knowledge, skills or information, provides young people with a resource with which to position themselves in a way to maximise the exchange value of their knowledge or education. Johanna Waters' research on family migration for children's education in the context of East Asia illustrates this well (Waters, 2006, 2014). She describes the practice of middle class families in East Asia relocating some of their family in countries such as the USA, Canada, Australia and New Zealand as part of a strategy to accumulate cultural capital to ensure the inter-generational reproduction of a family's social and economic status. While an initial glimpse reveals a picture of an archetypal transnational family for whom 'children's education' is an overriding concern, her analysis also describes a more complex, gendered pattern of experiences with mothers bearing the brunt of the burden of global householding and children playing a much more central role in the process of educational migration than previously assumed, and indeed, becoming a form of intergenerational 'capital themselves that enhances positioning in a global economic marketplace (Waters, 2014, 2017). 
This close link between social and cultural capital in education and migration is made by a number of other authors (Weenink, 2008, Devine, 2009). Devine's (2009) research on first-generation immigrant children in Ireland describes how children with well-educated parents were able to draw on valuable cultural and social capital in order to navigate the educational system in a new place. This included utilising considerable parental and community support for learning (for example, additional learning at the Muslim cultural centre). In contrast immigrant children who had less well-educated parents often had more difficulties in school, although many were still able to draw on rich social networks derived from ethnic and religious groups in the community. Importantly, Devine also illustrates how children across all backgrounds were not mere receptors of their family's capitals, but also contributed to processes of capital accumulation in families through, for example, coaching younger siblings, childcare and translating for families. Similarly, Weenick's research in Dutch International schools points out how families were strategically positioning their children within the internationalized streams in order to for them to gain 'cosmopolitan capital' in the form of languages, knowledge and dispositions that could equip them for future employment in the global field (see also Waters, 2017, for a description of 'linguistic capital').

In sum, these studies highlight how Bourdieu's concept of cultural capital has been applied to show how children can gain advantage and relative position through their access to knowledge or information, or their application of skills. This has served children from middle class families especially well, as it has enabled them to convert forms of cultural capital into economic advantage. In this way, the studies contribute to understandings of the tendency towards social reproduction in society, even to the extent to which aspirations have classbased origins (Gant, 2017, Holloway and Pimlott-Wilson, 2011). However, the studies also illustrate how children can be seen to be active in the production of cultural capital and not merely passive receptors (Waters, 2014, 2006, Devine, 2009, de Hoop, 2017). Waters (2014) points out that this enables children to be seen as 'sites of accumulation' (Katz, 2008) as they are central to the 'accumulation strategies' of migrant families, enabling a more agentic position for cultural capital to be seen.

Habitus: A smaller number of geographies of children researchers have utilised Bourdieu's concept of 'habitus'. This theoretical tool has generally been applied along with a close consideration of social class and how this influences the dispositions and orientations of individuals and groups. Allen's (2004) research with both 'privileged' and 'deprived' visually impaired children illustrates how habitus also has a sociospatial impact. His analysis showed 
that social class and disadvantage had a significant impact on children's embodied experiences of disability and space, with children and parents from less affluent backgrounds developing a 'deprived habitus' with reduced expectations of socio-spatial access and fewer practical strategies to resist the difficulties for visually impaired children. In contrast, Sparks (2016) describes how privileged young people express particular messages through their consumption patterns (economic and cultural capital) and displays of an embodied habitus of privilege.

Researching children's future aspirations for employment, Pimlott-Wilson (2011) similarly found that familial habitus had a strong influence on the types of jobs children aspired to, with children frequently replicating family traditions, as illustrated by Wayne: 'I'd like to work at a quarry like my dad coz, his granddad used to work there and he was a driver' (Pimlott-Wilson, 2011). Grant (2017) extends upon Pimlott-Wilson's study to demonstrate that habitus is also shaped through spatial (community) experiences as well as a sense of 'hope' which Grant argues can be a form of capital which in turn influences aspirations. His work shows the tight connection between Bourdieu's notion of capital and habitus and how together these shape young people's hopes and aspirations. These authors also found examples where these groups of children and their families moved beyond their expected habitus and adapted or changed their aspirations and expectations, illustrating that children are not passive recipients of socialisation, but also need to be seen to hold the potential to change their actions and aspirations, which resembles Bourdieu's understanding of reproduction and change outlined above.

Similar to studies on cultural capital, research on habitus also often had an educational focus. This is in keeping with Bourdieu's alignment understanding of the potential of habitus to be transformed through the actions of schooling (Bourdieu and Wacquant, 1992). This finding is confirmed in a number of educationally focused studies, which explore this tension of social reproduction and structural determinism against the liberating potential of education through schooling (Holloway and Pimlott-Wilson, 2011, Holt, 2008, Holt et al., 2013, Walker and Clark, 2010).

In sum, habitus, whilst a less commonly applied concept of Bourdieu's has the potential to combine the complex interrelationship between dominant social norms, individual socialisation experiences and actors' symbolic capital endowments. As a theoretical tool it 
offers avenues to expose both the socially deterministic aspects of social practice, but also the more transformative ones.

The overview above of some key papers which have applied Bourdieusian concepts shows that his theories have held a significant and growing role within a geographical analysis of children's lives. However, it is also possible to conclude that in some cases, the use of Bourdieu is 'light' and not as fully integrated or applied as it might be. Researchers tend to use a single concept from Bourdieu (such as social capital) and only a few apply his conceptual triad or fuller theoretical model (theory of practice) in a wider way. This is despite Bourdieu's (1997) insistence that an account of the structure and functioning of the social world necessitates an understanding of capital in all its interrelated forms. In relation to studies of children, Morrow (2001) argues that social capital in particular needs to be conceptualised in relation to other capitals if we are to examine children's resources in any depth, and Holt $(2008,240)$ similarly suggests that social capital needs to be seen as a constitutive component of "wider socio-spatial processes operating on a variety of intersecting spatial scales to reproduce / transform inequalities."

The work of researchers applying Bourdieu to studies of children and space has nonetheless contributed to theoretical developments in this area. Nicole Schaefer-McDaniel's (2004) framework for examining children's social capital helpfully proposed three dimensions that need exploring: social networks and sociability (children's interactions and relationships), trust and reciprocity, and sense of belonging/place attachment (the sense of community and symbolic attachment to place). In her framework, these three elements are grounded in the physical, everyday environments in order to:

... identify areas that enhance or foster social interactions as well as recognise areas that restrict or prohibit such activity. Spaces that enhance social interactions and a sense of belonging [...] thus can contribute to building social capital. (Schaefer-McDaniel, 2004, 166)

Importantly, Schaefer-McDaniel urges that social capital must be explored by talking to children themselves rather than their parents or teachers (see also Morrow, 2001). Such research suggests the potential for a more explicitly spatialised and integrated use of Bourdieu's theories which we illustrate in the following section.

\section{Section III: Applying Bourdieu's conceptual triad: Two studies}


In the final section of this chapter, two further examples are illustrated that show how the application of Bourdieu's conceptual triad in two different contexts elicited fresh insights into research on children and space. For each study, an overview of the research focus is provided, followed by a specific examination of Bourdieu's application, concluding with a summary of the analytical distinction through Bourdieu that the study provided.

\section{A) Ergler's study}

Focus of the study:

Children's declining physical activity levels and independent mobility in light of urban intensification and sustainability debates were drivers for Ergler's study on Auckland families' practices, experiences and feelings on playing in the outdoors during summer and winter. Data for this exploratory case study were derived from 72 semi-structured interviews, drawings, neighbourhood walks and GPS logs with 20 children (8-11years) and interviews with their parents. An urban/suburban contrast was made within the study between families from low socio-economic backgrounds who lived in high-rise apartment complexes in the inner city of Auckland and families with detached houses and gardens in the coastal suburb of Beach Haven in order to explore the socio-spatial differences and similarities in the utilisation and appreciation of outdoor activities within intensifying urban environments (Ergler, 2011, Ergler, forthcoming).

The choice to use Bourdieu's theory of practice as a guiding theoretical tool kit was made early in the research process. Prior studies in this area have tended to conceptualise the built environment as a container space that either provided or lacked resources to foster or hinder participation in healthy activity levels (Pearce and Witten, 2010), while explanations for the differences in behavioural patterns have largely neglected societal influences (e.g. axes of difference, norms and rules) and institutional structures (Swinburn et al., 1999). Similarly, seasonal and weather conditions were viewed as fuzzy moderators structuring outdoor activities from above (Tucker and Gilliland, 2007), rather than features which could shape embodied practices in the social and physical fabric of a neighbourhood. Bourdieu's theory of practice was therefore chosen as it could account for, and make sense of, the complex lived social realities of participants that previously had only been reported as 'outliers' or an inconsistency in findings, thus contributing to the limited success of many interventions promoting active play (see also Blacksher and Lovasi, 2012). Operationalising Bourdieu's 
theory of practice in the context of active play provided an opportunity to move beyond narrowly viewed context-related explanations for the decline in families' physical activity levels and unpack the deeper meaning of place-based determinants and social structures that shape, and are shaped by, families' lived social realities of engaging in outdoor play. It also provided opportunities to account for the interplay of structural and agential dimensions of social play realities in different places rather than focusing solely on one or the other.

\section{Applying Bourdieu's conceptual triad:}

Bourdieu suggests in his essay 'Sport and Social Class', that peoples' embodied dispositions and their (non)participation in different sporting activities are the result of the complex interrelationships between social struggles and aspirations in this field, actors' capital endowments and their habitus (Bourdieu, 1978). Applying this to the context of active outdoor play meant getting an idea about how struggles in the field of 'play' developed over time, awarding some forms of 'play' with greater value or, in Bourdieu's terms, symbolic capital.

Findings showed that the exposure to a certain habitat (neighbourhood, lifestyle) cultivated particular affinities in families for outdoor play. These in turn reflected locally constituted beliefs about which child activities are 'appropriate' in different seasons (e.g. spending time on the playground, staying indoors) (Ergler et al., 2013b). While independent outdoor play across seasons was deemed possible under certain circumstances in the suburb, in the central city it was seen as largely 'inappropriate'. In the commercial environment of the inner city, parents showed a greater preference for interior and supervised pastimes. Outdoor play was less valued all-year-round due to perceived dangers (e.g. traffic, stranger-danger), but also due to the 'looks' families encountered when being out and about. These looks signalled them that the inner city has been designed for adults rather than families with children. As a consequence, children were enrolled in extra-curricular activities and/or after school programs and when children wanted to play in a park or playground they needed to rely on parents to take them.

In contrast, independent outdoor play in summer was commonplace for the majority of the suburban children after school. Parents (and sometimes also children) saw such activities as facilitating children's 'environmental literacy' and future health and therefore were weighted with high symbolic capital (Ergler et al., 2013b). For a minority of families in the suburbs this symbolic value was replaced by safety concerns. Nonetheless, summer for these 
families carried the connotation of a long play time, of being out and about, of spending afternoons and weekends playing in parks and beaches with friends, families and relatives. For both inner city and suburban families play was regarded differently in winter, with more marked differences apparent for the suburban families from summer play. It seems that even in a mild climate like Auckland a practical sense developed in which winter is the time to relax and stay indoors with the exception of some children who had an 'outdoor habitus' all year round.

Many families saw playing outdoors as a way to equip children with environmental, social and cultural capital. With these accounts, parents echo scholarly findings that children learn through play (Malone, 2007, Harker, 2005, Moore, 1986). They gain confidence and self-esteem as well as cognitive and mental capabilities, but they can also build and further their 'imaginary' capital through creatively transforming their play environment (e.g. a rock becomes a pirate ship). This also enhances other forms of symbolic capital (e.g. social capital, cultural sensitivity). For example, children can increase their cultural capital by being exposed to ethnic and socio-economic diversity when being out and about, which in turn raises their awareness to difference in for example social practices, dress styles and interactions not only between children, but also in the adult world. In families with an outdoor habitus, parents had often been 'free ranging' kids themselves triggering the embodied belief that independently mobile children get 'streetwise' and will benefit later in life from their ability to handle the complexities of a multifaceted world (see also Malone, 2007).

In contrast, in the eyes of the many families (especially in the central city) with a curtailed habitus, independent play was deemed not suitable for maximising children's development. Their aspiration was to offer their children a 'better' life through enrolment in extra-curricular activities. For these families, playing was discursively linked to institutionalised learning in order to provide their children with the necessary cultural and social capital for a better start in their adulthood life and an upward social mobility (Ergler et al., 2016). While these findings are not novel in themselves, viewing them through a Bourdieusian lens allowed for an opportunity to embed this study within broader power trajectories of the social space (field) - as a site and product of struggle - within which families operate in, comply with, or resist. It is possible therefore to view the changing value of play over time as the outcome of broader market forces, and local and national policies and not just personal decisions (Ergler et al., 2013a). 


\section{Summary}

Bourdieu's theoretical toolkits of field, capital and habitus offer a framework to explain how and why children in different neighbourhoods and from different family backgrounds engaged (or did not engage) in outdoor play during summer and/or winter in an intensifying urban environment. This enabled a nuanced and place-based view on the complex social and environmental determinants shaping 'obesogenic environments' (environments that help, or contribute to, obesity mainly on a structural level e.g. design of cities, policies). It alerted the researcher to pay attention to the complex and recursive relationship of locality, seasonality and (historical) practices that inform and are shaped by different play dispositions, symbolic capitals and the seasonally 'appropriate' play activities in the field of 'play'. This study also highlighted the importance of understanding families' logic of practice and their embodied familial, societal and locational history, rather than trying to 'fix' narrowly defined social and environmental determinants.

\section{B) Wood's study}

Focus of study:

The focus of Wood's research was on New Zealand young people's perceptions and practices of active citizenship in light of a curriculum requirement for them to 'take social action' as a result of their learning in the social studies curriculum. Applying a comparative case study approach, she purposively selected four schools from a variety of cultural, geographic and socio-economic contexts. Teachers $(n=27)$ and students $(n=122)$ were invited to participate at each of these schools and data collection involved classroom observations, focus groups interviews, participatory visual methodologies and poster creation (students only).

The decision to apply Bourdieu was not made until the research was well underway, as it became apparent that there were significant differences in how active citizenship was perceived and practised between schools from lower and higher social economic backgrounds. In particular, there were differences in the spatial orientation with lower socioeconomic schools holding more locally focused beliefs and practices, and higher socioeconomic schools demonstrating more nationally and globally focused spatial orientations. This finding was not in itself novel: citizenship research has previously shown that landscapes of citizenship participation are far from even, with young people from economically 
disadvantaged backgrounds having lower rates of civic and political participation (Lopes et al., 2009, Black, 2011, Spring et al., 2007). Moreover, there is also evidence that the structured lived experiences (class, gender and ethnicity) significantly affect the way young people negotiate their citizenship identities (Marsh et al., 2007). However, the theoretical challenge was to find a way to explain how and why these school communities held different ways of thinking and doing. Bourdieu's conceptual triad and his concept of doxa became a way to explain these varying outcomes.

\section{Applying Bourdieu's conceptual triad:}

Bourdieu suggests that an individual's dispositions and actions (practice) can be seen as a reflection of the inseparable interplay of habitus, capital and field (Bourdieu, 1984). Applying this to the context of citizenship participation meant looking at how the assets and resources, or 'capital' (in the form of social networks, knowledge, skills and dispositions) held by children and teachers in school communities could explain the differences in the nature, practices and spatial outlook of active citizenship. An analysis across and within schools using Bourdieu's idea of a 'field', or the social space within which individuals operate, showed that each school community had its own logic, networks and practices that were specific to that field (Bourdieu and Wacquant, 1992). Viewing a school or department as a social field on a micro-level (Mutch, 2006) provided a way to examine how the interaction of capital and habitus in that field created differing outcomes in terms of perceptions and practices and active citizenship.

One key way to explain the differences in civic knowledge and dispositions observed within these school communities is to examine the differing levels of cultural capital held by community members. In relation to citizenship, less advantaged backgrounds and lower levels of civic knowledge have been found to result in lower levels of civic participation, though not necessarily less interest in political issues (Schulz et al., 2010). Similarly, McFarland and Thomas (2006) found that young people from wealthier, higher educated families, as well as young people from all social backgrounds who had participated in political and social volunteering as youth, both had higher levels of 'political capital' as adults later in life. In Wood's study, these differences in cultural capital mirrored this pattern in the spatial orientation and focus of social issues studied. The students and teachers in the two higher SES schools discussed global issues more than local, and often were involved in global initiatives and organisations (such as the Red Cross), while the poorer school communities tended to focus on immediate issues and action in their own community (Wood, 2012, 2013). This was 
further reinforced by varying opportunities to gain new knowledge and skills of civic understandings and actions through opportunities through the school. In the higher socioeconomic schools, students were offered school trips to developing nations to undertake service-and compassion-related activities. The economic capital in these schools enabled students to do this, while these opportunities were not even offered in poorer schools as it was unlikely parents could afford such trips.

Such distinctions were not so apparent with the levels of social capital in the different school communities. Social capital is held to be an important driver of civic action "because it facilitates the development of the type of co-operative social relations that are a prerequisite of collective action" (Fahmy, 2006). Across all the four schools, young people's social networks and sociability, levels of trust and reciprocity and sense of belonging within their neighbourhoods and communities shaped their civic participation. Unlike cultural capital, there was less apparent symbolic value attached to certain forms of social capital, although further research could reveal that wider international social networks could carry greater value than more locally-focused ones.

Wood $(2013,2015)$ surmises that the combined and interrelated social, economic and cultural capital related to the logic, network and practices of citizenship participation within a social field can be viewed as 'participatory capital' (Wood, 2013). The social context which this occurs in (field) then operates to distinguish between forms of participatory capital that receive distinction, resulting in differing forms of symbolic participatory citizenship dispositions and actions. In light of the current educational imperative to prepare young people towards global flows of capital and employment, it is likely that young people holding more globally-oriented participatory capital would have a form of symbolic value (Bourdieu's symbolic capital) in that it could be traded and marketed as a more powerful economic asset than locally focused active citizenship.

While less of a focus was made on habitus in this study as familial data was not collected from students, it was apparent that school communities shared unquestioned beliefs, or, in Bourdieu's (1990) terms, doxa within a specific field. In this study, the diverse perceptions and practices held by these four schools were socially and culturally constituted and reinforced by a shared set of unquestioned beliefs or doxa within these school communities (Wood, 2015). The findings highlight the significance of teachers' shared identities within school departments and communities and how these identities shaped their own and their students' understandings and spatial interpretations of citizenship curricula. 


\section{Summary:}

Bourdieu's conceptual triad (habitus, field and capital) provides a broad conceptual framework through which to explore youth participatory citizenship. These three concepts alert the researcher to pay particular attention to how young people's interactions with family and teachers with spatial communities, as well as their exposure to aspects of participation through their school programmes, informs their citizenship actions, dispositions and identities.

\section{Concluding thoughts}

The analysis in this chapter reveals that while Bourdieu's theoretical concepts of habitus, capital and field have not been ignored by researchers of children and young people's geographies, they have generally only been applied lightly or singularly, rather than integrating his full conceptual triad. This is not surprising given that children's geographies only gained currency and acknowledgement as a sub-discipline in recent years (Holloway, 2014). Working with children and young people in order to inform existing or develop new socio-spatial conceptualisations is still relatively novel. While Bourdieu's conceptual tools have been advanced and modified to deal with the complexities of everyday life of adults in the $21^{\text {st }}$ century, this chapter has shown the operationalization of his tool kit in children's and young people's geographies is still in its infancy.

The chapter also shows that the work in children's geographies has begun to open new and different conversations about the social, physical and spatial nature of children's lives through engaging with Bourdieu, and that this holds great potential for further developments in this field. . In particular, studies that have placed children, rather than adults, as the central focus, and through the integration of Bourdieu's conceptual triad, have sharpened the gaze on to the life circumstances of children, as well as the role children themselves play in shaping and reshaping socio-spatial axes of inequality. Bourdieu's notion of social capital, has provided a way to see the role that children play as agents in creating and advancing social capital (Holland, Reynold and Weller, 2007; Schaefer-McDaniel, 2004; Weller, 2006; Weller and Bruegel, 2009), as well as enhance familial social and cultural capital through, for example, decision-making about educational migration (Waters, 2006; 2017). Other studies applying Bourdieu have shed light on the ongoing structural constraints of children in education or urban environments as a result of their habitus and the social, cultural and economic capital they inherit, alongside the potential for children to also resist or break free 
from these constraints (Allen, 2004; Grant, 2017, Holloway and Pimlott-Wilson, 2011; Wood, 2013; Ergler et al., 2013).

As Holt $(2008,241)$ highlights, Bourdieu's theory of practice is able "to reconnect broader embodied differences to wider socio-spatial processes including the political economy, without entirely reducing such differences to the realm of historical-materialist relations". Theoretically this provides an opportunity to move beyond solely viewing children as autonomous social actors, or alternatively, viewing them solely as products of institutional and socio-political structures. Bourdieu's theory of practice can therefore account for the multiple and diverse struggles of children, their families and communities, the norms and rules that structure the value of their different symbolic capitals and how in turn these shape their dispositions and actions (Ergler and Wood, 2015). Or in other words, Bourdieu's theories draw attention to children's doings and beings, their place-based experiences, the deeply social nature of their agency and their ability and constraints to transform and bring about social change. This approach not only allows a reconnection between place-based experiences and wider global processes in their historical trajectories, but also provides a powerful theoretical and explanatory toolkit to move beyond the 'how' and conceptualise 'why' these seemingly arbitrary logics create socio-spatial inequalities that are then maintained and entrenched.

In concluding we suggest two further ways that Bourdieu could be utilised more extensively and deeply within children's and young people's geographies thus taking up Bourdieu's invitation "to transcend the circumscribed intellectual context and empirical terrain of its initial enunciations...to out-think" him (Bourdieu \& Wacquant, 2007, p.xiii). Firstly, as the discussions on symbolic capital showcased, there is a great deal of potential to advance Bourdieu's ideas further. For example, in her reflections on Bourdieu and children's geographies, Mayall (2012) suggests that his work on 'field' offers a great deal of potential for geographers who are looking to integrate ideas of space and place, and structure and agency. Indeed, the well-developed notions of place and identity in geography offer many possible avenues to account for and further develop fine-grained understandings of sociospatial inequalities. For example, by combining the diverse nodes coming together within places (Massey, 2005) and different groups' experiences of the layers of history in places (Panelli et al., 2008) with Bourdieu's theory of practice could provide an opportunity to conceptualise children's place-based beings and doings within the micro and macro 'fields' of their lifeworlds. 
Secondly, while children and young people's geographers have developed diverse and complex methods to gain insights in children's mundane everyday experiences and have worked to overcome or minimise the influence of power relationships between child participants and adult researchers during the research process (Johnson et al., 2017), these methodological discussions rarely are integrated with theoretical and empirical discussions. However, as Bourdieu $(1996,8)$ highlights, to make full use of his theory of practice, these components cannot be viewed separately:

The notions of social space, symbolic space, or social class are never studied in and for themselves; they are tested through research in which the theoretical and the empirical are inseparable, and which mobilizes a plurality of methods of observation and measurement, quantitative and qualitative, statistical and ethnographic, macrosociological and microsociological.

Thus, only by applying more sensitivity to the engagement with and reflexivity of all three components simultaneously, it is possible to realise the advantages of a Bourdieusian way of thinking to its full "potential" (Grenfell, 2008b); to reflect not only on the researchers and participants' positionality, but also disciplinary positionalities and methodological principles and how these influence the micro and macro theoretical conceptualisations and empirical findings. Such an approach in turn may open up new and interesting avenues to inform and advance children's sociospatial axes of inequalities and move beyond narrow discussions on power relations and the 'right' child-friendly methods.

To conclude, this chapter has provided a snapshot of the disciplinary engagements of children's geographies with one of the foremost social philosophers of the twentieth century. This review has highlighted a number of growing strengths in the sub-discipline and also opportunities to enrich this research further. It has opened up discussions for developing Bourdieu's theory of practice further and build on the fine-grained tool kit his theory of practice offers for analysing the social and physical nature of social realities in and beyond children's and young people's geographical spaces. 


\section{References}

AITKEN, S. 2001. Geographies of young people, the morally contested spaces of identity, London, Routledge.

ALLEN, C. 2004. Bourdieu's habitus, social class and the spatial worlds of visually impaired children. Urban Studies, 41, 487-506.

ASPLUND, S.-B. \& PRIETO, H. P. 2013. 'Ellie is the coolest': class, masculinity and place in vehicle engineering students' talk about literature in a Swedish rural town school. Children's Geographies, 11, 59-73.

BLACK, R. 2011. Students participation and disadvantage: Limitations in policy and practice. Journal of Youth Studies, 14, 463-474.

BLACKSHER, E. \& LOVASI, G. S. 2012. Place-focused physical activity research, human agency, and social justice in public health: Taking agency seriously in studies of the built environment. Health \& Place, 18, 172-179.

BOURDIEU, P. 1977. Outline of a theory of practice, Cambridge, Cambridge University Press.

BOURDIEU, P. 1978. Sport and social class. Social Science Information, 17, 819-840.

BOURDIEU, P. 1984. Distinction: A social critique of the judgement of taste, London, Routledge \& Kegan Paul.

BOURDIEU, P. 1986. The forms of capital. In: RICHARDSON, J. (ed.) Handbook of theory and research for the sociology of education. Westport, CT: Greenwood.

BOURDIEU, P. 1990. The logic of practice, Stanford, Stanford University Press.

BOURDIEU, P. 1996. Physical space, social space and habitus. Oslo: Institutt for sosiologi og samfunnsgeografi Universitetet i Oslo.

BOURDIEU, P. 2000. Pascallian meditations, Cambridge, Polity.

BOURDIEU, P., ACCARDO, A., BALAZS, G., BEAUD, S., BONVIN, F., BOURDIEU, E. \& BURGOISE, P. 1999. The weight of the world: social suffering in contemporary society., Cambridge, UK, Polity Press.

BOURDIEU, P. \& WACQUANT, L. 1992. An invitation to reflexive sociology, Chicago, The University of Chicago Press.

BRIDGE, G. 2004. Pierre Bourdieu. In: HUBBARD, P., KITCHIN, R. \& VALENTINE, G. (eds.) Key Thinkers on Space and Place. Sage.

BUTLER, J. 1999. Performativity's social magic. In: SHUSTERMAN, R. (ed.) Bourdieu: a critical reader London: Blackwell.

COLEMAN, J. S. 1988. Social capital in the creation of human capital. The American Journal of Sociology, 94, 95-120.

CRESSWELL, T. 2002. Bourdieu's geographies: In memorium. Environment and Planning D: Society and Space, 20, 379-382.

CROSSLEY, N. 2008. Social class. In: GRENFELL, M. (ed.) Pierre Bourdieu: Key concepts. Durham: Acumen Publishing Ltd.

DEVINE, D. 2009. Mobilising capitals? Migrant children's negotiation of their everyday lives in school. British Journal of Sociology of Education, 30, 521-535.

DE HOOP, E. 2017. Multiple environments: South Indian children's environmental subjectivities in formation. Children's Geographies, 15, 570-582.

ERGLER, C. R. , KEARNS, R. A. \& WITTEN, K. 2016. Exploring children's seasonal play to promote active lifestyles in Auckland, New ZealandHealth and Place, 41, 67-77.

Ergler, C. R. forthcoming. The Power of Place in Play. Bielefeld: Transcript.

ERGLER, C. R., KEARNS, R. \& WITTEN, K. 2013a. Managed childhoods: a social history of urban children's play. In: HIGGINS, N. \& FREEMAN, C. (eds.) Childhoods: growing up in Aotearoa New Zealand. Dunedin: University of Otago Press. 
ERGLER, C. R. \& WOOD, B. E. 2015. Revisiting and re-imagining youth participation in the 21st Century. In: KELLY, P. \& KAMP, A. (eds.) Critical Youth Studies for the 21st Century. Leiden: Brill.

ERGLER, C. R. 2011. Beyond passive participation: children as collaborators in understanding neighbourhood experience Graduate Journal of Asia-Pacific Studies, 7, 78-98.

ERGLER, C. R., KEARNS, R. A. \& WITTEN, K. 2013b. Seasonal and locational variations in children's play: Implications for wellbeing. Social Science \& Medicine, 91, 178-185.

FAHMY, E. 2006. Social capital and civic action: A study of youth in the United Kingdom. Young, 14, 101-118.

FUKUYAMA, F. 2001. Social capital, civicl society and development. Third World Quarterly, 7-20.

GIDDENS, A. 1998. The Third way: The renewal of social democracy, Malden, Polity Press.

GOODWIN, M. \& ARMSTRONG-ESTHER, D. 2004. Children, social capital and health: increasing the well-being of young people in rural Wales. Children's Geographies, 2, 49-63.

GRANT, T. 2017. The complexity of aspiration: the role of hope and habitus in shaping working-class young people's aspirations to higher education. Children's Geographies, 15, 289-303.

GREGORY, D. 1994. Geographical imaginations, Cambridge, MA, Blackwell.

GRENFELL, M. 2008a. Introduction. In: GRENFELL, M. (ed.) Pierre Bourdieu: Key concepts. Durham: Acumen Publishing Ltd.

GRENFELL, M. 2008b. Postscript: methodological principles. In: GRENFELL, M. (ed.) Pierre Bourdieu: key concepts. Stocksfield: Acumen.

HARKER, C. 2005. Playing and affective time-spaces. Children's Geographies, 3, 47-62.

HARKER, R. 1990. Bourdieu - Education and reproduction. In: HARKER, R., MAHAR, C. \& WILKES, C. (eds.) An introduction to the work of Pierre Bourdieu: The practice of theory. Houndsmills: The Macmillan Press Ltd.

HARVEY, D. 1987. Flexible accumulation through urbanization: reflections on 'post-modernism' in the American city. Antipode, 19, 260-286.

HARVEY, D. 1989. The condition of postmodernity: an enquiry into the origins of cultural change, Oxford, Blackwell.

HILLIER, J. \& ROOKSBY, E. 2002. Introduction. In: HILLIER, J. \& ROOKSBY, E. (eds.) Habitus: A sense of place. Aldershot: Ashgate.

HOLLAND, J. 2008. Young people and social capital: What can it do for us? Available: http://www1.Isbu.ac.uk/ahs/downloads/families/familieswp24.pdf.

HOLLINGWORTH, S., WILLIAMS, K., JAMIESON, F. \& BEEDELL, P. 2011. Social and spatial inequalities in English state schools. In: HOLT, L. (ed.) Geographies of children, youth and families: International PerspectivesOxon/NY. Oxon/NY: Routledge.

HOLLOWAY, S. 2014. Changing children's geogarphies. Children's Geographies, 12, 4, 377-392

HOLLOWAY, S. \& PIMLOTT-WILSON, H. 2011. The politics of aspiration: neo-liberal education policy, 'low' parental aspirations, and primary school Extended Services in disadvantaged communities. Children's Geographies, 9, 79-94.

HOLT, L. 2008. Embodied social capital and geographic perspectives: Performing the habitus. Progress in Human Geography, 32, 227-246.

HOLT, L. 2010. Young people's embodied social capital and performing disability. Children's Geographies, 8, 25-37.

HOLT, L. 2011. Geographies of children, youth and families: An international perspective, Oxon/NY, Routledge.

HOLT, L., BOWLBY, S. \& LEA, J. 2013. Emotions and the habitus: Young people with socio-emotional differences (re)producing social, emotional and cultural capital in family and leisure spacetimes. Emotion, Space and Society, 9, 33-41.

HOLTON, M. 2014. The geographies of UK university halls of residence: examining students' embodiment of social capital. Children's Geographies, 1-14.

HÖRSCHELMANN, K. \& VAN BLERK, L. 2012. Children, youth and the city, Abingdon, Routledge. 
JENKINS, R. 1992. Pierre Bourdieu, London, Routledge.

JENSEN, K. B. 2015. Learning Skills, Building Social Capital, and Getting an Education: Actual and Potential Advantages of Child Domestic Work in Bangladesh. In: ABEBE, T., WATERS, J. \& SKELTON, T. (eds.) Labouring and Learning. Singapore: Springer Singapore.

JOHNSON, V., HART, R. \& COLWELL, J. 2017. International Innovative Methods for Engaging Young Children in Research. In: EVANS, R. \& HOLT, L. (eds.) Methodological Approaches. Singapore: Springer Singapore.

KENWAY, J. \& MCLEOD, J. 2004. Bourdieu's reflexive sociology and 'spaces of points of view': whose reflexivity, which perspective? British Journal of Sociology of Education, 25, 525-544.

KATZ, C. 2008. Childhood as spectacle: Relays of anxiety and the reconfiguration of the child. Cultural Geographies, 15, 5-17.

LOPES, J., BENTON, T. \& CLEAVER, E. 2009. Young people's intended civic and political participation: Does education matter? Journal of Youth Studies, 1, 1-20.

LOSSAU, J. \& ROLAND, L. 2004. Geographie und spatial turn (Geography and the Spatial Turn). Erdkunde, 58, 201-211.

MALONE, K. 2007. The bubble-wrap generation: children growing up in walled gardens. Environmental Education Research, 13, 513 - 527.

MARSH, D., O'TOOLE, T. \& JONES, S. 2007. Young people and politics in the UK: Apathy or alienation?, Basingstoke, Palgrave MacMillan.

MASSEY, D. B. 2005. For space, London, Sage.

MAYALL, B. 2012. An afterword: some reflections on a seminar series. Children's Geographies, 10, 347-355.

MCFARLAND, D. \& THOMAS, R. 2006. Bowling young: How youth voluntary organisations influence adult political participation. American Sociological Review, 71, 401-425.

MOORE, R. 2008. Capital. In: GRENFELL, M. (ed.) Pierre Bourdieu: Key concept, (101-117). Durham: Acument Publishing Ltd.

MOORE, R. C. 1986. Childhoods's domain: Play and places in child development, London, Croom Helm.

MORROW, V. 1999. Conceptualising social capital in relation to the well-being of children and young people. Sociological Review, 47, 744-766.

MORROW, V. 2000. 'Dirty looks' and 'trampy places' in young people's accounts of community and neighbourhood: Implications for health inequalities. Critical Public Health, 10, 141-152.

MORROW, V. 2001. Young people's explanations and experiences of social exclusion: retrieving Bourdieu's concept of social capital. International Journal of Sociology and Social Policy, 21, 37-63.

MUTCH, C. 2006. Adapting Bourdieu's field theory to explain decision-making processes in educational policy. In: ANFARA, V. \& MERTZ, N. (eds.) Theoretical frameworks in qualitative research. Thousand Oaks: Sage.

NÍ LAOIRE, C. 2011. 'Girls just like to be friends with people': gendered experiences of migration among children and youth in returning Irish migrant families. Children's Geographies, 9, 303318.

PAINTER, J. 2000. Pierre Bourdieu. In: CRANG, M. \& THRIFT, N. (eds.) Thinking space. London: Routledge.

PANELLI, R., ALLEN, D., ELLISON, B., KELLY, A., JOHN, A. \& TIPA, G. 2008. Beyond Bluff oysters? Place identity and ethnicity in a peripheral coastal setting. Journal of Rural Studies, 24, 41-55.

PEARCE, J. \& WITTEN, K. (eds.) 2010. Geographies of obesity: environmental understandings of the obesity epidemic, Aldershot: Ashgate.

PILE, S. \& THRIFT, N. 1995. Mapping the subject: geographies of cultural transformation, London/NY, Routledge.

PIMLOTT-WILSON, H. 2011. The role of familial habitus in shaping children's views of their future employment. Children's Geographies, 9, 111-118. 
POPAY, J., THOMAS, C., WILLIAMS, G., BENNETT, S., GATRELL, A. \& and BOSTOCK, L. 2003. A proper place to live: health inequalities, agency and the normative dimensions of space. Social Science \& Medicine, 57, 55-69.

PORTES, A. 1998. Social capital: Its origins and applications within modern sociology. Annual Review of Sociology, 24, 1-24.

PUTNAM, R. 1993. The prosperous community: Social capital and public life. The American Prospect, 4.

PUTNAM, R. 1995. 'Tuning in and tuning out': The strange disappearance of social capital in America. Political Science and Politics, 28, 664-683.

PUTNAM, R. 2000. Bowling Alone: The collapse and revival of American community, New York, Simon and Schuster.

RAFFO, C. \& REEVES, M. 2000. Youth transitions and social exclusion: Development in social capital theory. Journal of Youth Studies, 3, 147-166.

REYNOLDS, T. 2013. 'Them' and 'us': 'Black neighbourhoods' as a social capital resource among Black youths living in inner-city London. Urban Studies, 50, 484-498.

SCHAEFER-MCDANIEL, N. 2004. Conceptualizing social capital among young people: Towards a new theory. Children, Youth and Environments, 14, 153-172.

SCHULZ, W., AINLEY, J., FRAILLON, J., KERR, D. \& LOSITO, B. 2010. ICCS 2009 International Report: Civic knowledge, attitudes, and engagement among lower-secondary students in 38 countries ICCS. Amsterdam: IEA.

SPARKS, H. 2016. Exploring the Geographies of Privileged Childhoods. Geography Compass, 10, 253267.

SPRING, K., DIETZ, N. \& GRIMM, R. 2007. Leveling the pathway to participation: Volunteering and civic engagement amoung youth from disadvanted circumstances Youth helping America. . Washington DC: Corporation for National and Community Service.

STETTEN, G. 2009. Habitus. In: KITCHIN, R. \& THRIFT, N. (eds.) International Encylopedia of Human Geography. Oxford: Elsevier.

SWINBURN, B., EGGER, G. \& RAZA, F. 1999. Dissecting Obesogenic Environments: The Development and Application of a Framework for Identifying and Prioritizing Environmental Interventions for Obesity. Preventive Medicine, 29, 563-570.

THOMSON, P. 2008. Field. In: GRENFELL, M. (ed.) Pierre Bourdieu: Key concepts. Durham: Acumen PUblishing Ltd.

THREADGOLD, S. 2010. Should I pitch my tent in the middle ground? On 'middling tendency', Beck and inequality in youth sociology. Journal of Youth Studies, 14, 381-393.

TUCKER, P. \& GILLILAND, J. 2007. The effect of season and weather on physical activity: A systematic review. Public Health, 121, 909-922.

TURNER, S. \& AN NGUYEN, P. 2005. Young Entrepreneurs, Social Capital and Doi Moi in Hanoi, Vietnam. Urban Studies, 42, 1693-1710.

WALKER, M. \& CLARK, G. 2010. Parental choice and the rural primary school: Lifestyle, locality and loyalty. Journal of Rural Studies, 26, 241-249.

WATERS, J. 2006. Geographies of cultural capital: education, international migration and family strategies between Hong Kong and Canada. Transactions of the Institute of British Geographers, 31, 179-192.

WATERS, J. 2014. Educational imperatives and the compulsion for credentials: family migration and children's education in East Asia. Children's Geographies, 1-14.

WEENINK, D. 2008. Cosmopolitanism as a form of capital: Parents preparing their children for a globalizing world. Sociology, 42, 1089-1106.

WELLER, S. 2006. Skateboarding alone: Making social capital discourse relevant to teenagers' lives. Journal of Youth Studies, 9, 557-574.

WELLER, S. \& BRUEGEL, I. 2009. Children's 'place' in the development of neighbourhood social capital. Urban Studies, 46, 629-643. 
WELLS, K. 2011. The strength of weak ties: the social networks of young separated asylum seekers and refugees in London. Children's Geographies, 9, 319-329.

WOOD, B. E. 2012. Scales of citizenship: New Zealand teacher's diverse perceptions and practices. International Journal of Progressive Education [Online], 8. Available: http://inased.org/v8n3/ijpev8n3.pdf.

WOOD, B. E. 2013. Participatory capital: Bourdieu and citizenship education in diverse school communities. British Journal of Sociology of Education, 35, 578-597.

WOOD, B. E. 2015. Participating as young citizens in diverse communities. In: WYN, J. \& CAHILL, H. (eds.) Springer Handbook of Youth and Childhood Studies. Netherlands: Springer.

WOOD, B. E. 2015. Teacher interpretations of 'active' citizenship curricula: Shared identities and spatial orientations In: ERYAMAN, M. \& BRUCE, B. (eds.) Handbook of Progressive Education. 339-354. NY: Peter Lang. 